\title{
The Quality of Water Sources of Two Towns in Arid Region During a Drought Year: A Study of Musina \& Beitbridge Towns
}

\author{
Tshifhiwa Shelter Muntswu and Jabulani Ray Gumbo
}

\begin{abstract}
Drought is a natural feature of hydrology, which is influenced by climate change, and has the ability to cause water quality implications for drinking purpose, through proliferation of harmful cyanobacterial blooms due to the occurrence of current high temperatures and heat waves. The study assessed the 2016 drought on drinking water quality for Musina town in South Africa and Beitbridge town in Zimbabwe and their raw water supplies. The water samples were collected from drinking water taps and raw water supply sources for physical-chemical analysis and molecular analysis for the determination of cyanobacteria genes expressing toxicity. The $\mathrm{pH}$ of the water sources was in the range of 6.85 to 7.72 . The electrical conductivity was in the range of 591.67 to $1026 \mu \mathrm{S} / \mathrm{cm}$. The water temperature was in the range of 22.63 to $34.2{ }^{\circ} \mathrm{C}$. The turbidity was in the range of 0.00 to 2.04 NTU. The nitrate and soluble phosphates levels were in the range of 1.2 to $11.7 \mathrm{mg} / \mathrm{l}$ and 0.5 to $3.5 \mathrm{mg} / \mathrm{l}$. The heavy metals were higher in the water samples during the month of October in comparison with cooler month of July. The molecular techniques showed the presence of toxic cyanobacteria genes, $c y r$, and the cylindrospermopsin toxin in both Limpopo River (weir \& borehole) and Musina tap water samples during July and October period. The Beitbridge tap water was free of genes expressing cyanobacteria toxicity. The study showed the presence of genes expressing toxicity for the cylindrospermopsin cyanotoxin in some of the water samples. The cyanotoxin may be attributed to toxic cyanobacteria which proliferate due to favourable environmental weather conditions.
\end{abstract}

Keywords - (Drought, Cyanobacteria, Toxins, Water Quality)

\section{INTRODUCTION}

Drought, which is difficult to predict, is a natural feature of the hydrology in most regions. Climate change has the potential to increase the frequency and magnitude of future drought. While the lack of water availability during droughtis widely publicized, there are equally severe water quality impacts that occur during and after drought events. Recent drought has led to water quality implications for drinking

Manuscript received October 20, 2020.August 9, 2014

Ms Tshifhiwa Shelter Muntswu is with the National Disaster Management Centre, Department of Cooperative Governance.

Prof Jabulani Ray Gumbo is with the Department of Hydrology \& Water Resources, University of Venda water supplies including turbidity, taste and odor, pathogen concerns, and challenges in managing disinfection byproducts [1]. Drought is a major concern for utilities and water resource managers worldwide due to the far-reaching impacts of constrained water supplies.

Increase in heat addition, causes drought increase over a particular period of time, and thus causing tragic impacts in many regions of the world [1,2]. In addition to the potential for future changes to water quality, the trend towards increasingly strict drinking water regulations is expected to continue. The combination of decreased water quality with lower maximum contaminant levels may result in vulnerabilities for many utilities, requiring substantial investment in updated treatment technology to maintain compliance.

High temperatures, heat waves and drought conditions experienced in 2016 [3] in South Africa have led to the proliferation of cyanobacteria blooms [4]. The study of Magonono et al. [5] on the quality of drinking water for Musina Local Municipality indicates the presence of the cyanobacteria species and harmful toxins. The nutrients, nitrates and phosphates are readily available in water column due to discharge of partially treated sewage effluent. The objective of the study was to assess the water quality of raw water supply and treated drinking water for Musina and Beitbridge Towns during a drought year of 2016. The specific objectives were to determine the physical-chemical $(\mathrm{pH}, \mathrm{EC}$, turbidity, nitrates, phosphates), to determine the levels of trace and heavy metals and to determine the presence/absence of cyanobacteria genes expressing of toxicity.

\section{MATERIALS AND METHODS}

\section{A. The study area}

The study areas are Musina \& Beitbridge towns which are situated in the Vhembe district of Limpopo province, South Africa \& Matabeleland South province in Zimbabwe respectfully (Figure 1). Musina Local Municipality receives its drinking water supply from 19 boreholes which are in the Limpopo River. The raw water supply for Beitbridge town comes from a weir constructed in the Limpopo River and for Musina town comes from 22 boreholes of which 14 are drilled along the Limpopo River and 8 boreholes are drilled inside the Limpopo River [6]. Beitbridge town receives its drinking water 
from Zimbabwe National Water Authority water treatment plant which receives its raw water supply from weir built in the Limpopo River [7].

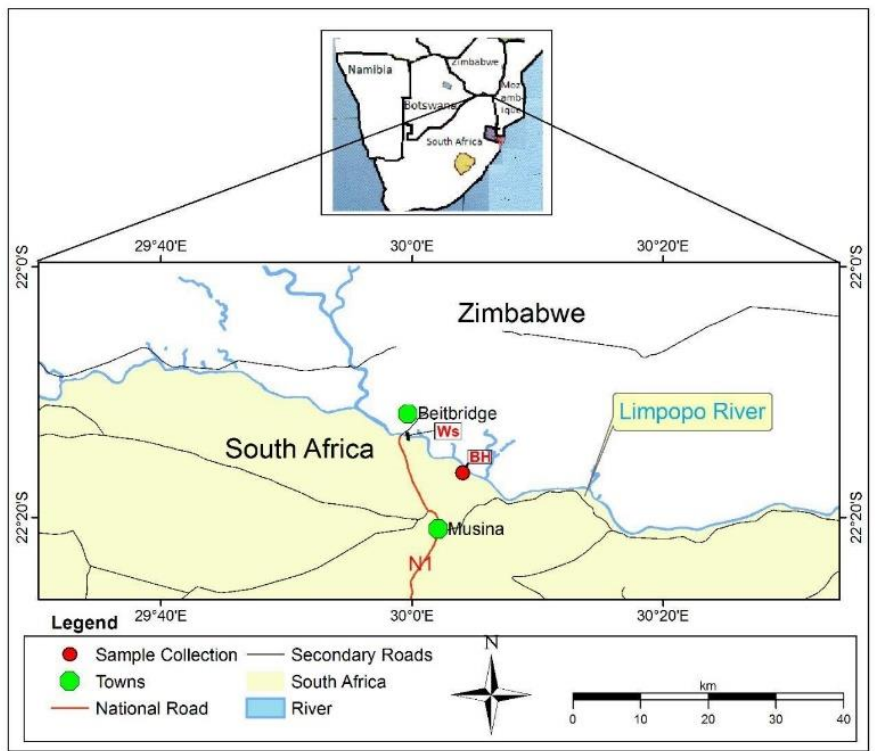

Fig. 1: The location of Musina town and Beitbridge town and the raw water supply sources. BH is the borehole inside the Limpopo River providing raw water supply for Musina town and Ws is a weir on the

Limpopo River providing raw water supply for Beitbridge town.

\section{B. Water sampling points}

To meet the objectives of the study, four sampling points were selected, which includes the upstream Limpopo boreholes (S1), Musina water tap (S2), downstream Beitbridge town water tap (S3), and Limpopo weir (S4). Two raw water samples were collected from each site, for the purpose of results accuracy (in July and October 2016), giving a total raw of 16 water samples. The water samples were preserved in a refrigerator at $4{ }^{\circ} \mathrm{C}$ to slow down the chemical reaction and to keep the water content in contact until analysis were carried out.

Water samples were collected once using a new high-density (HDPE) screw-capped containers (plastic container of $175 \mathrm{ml}$ and a glass container of $375 \mathrm{ml}$ ).

\section{Physical-chemical analysis}

The determination of physical parameters

A multimeter instrument (H19829) was used to measure on-site, $\mathrm{pH}$, Electrical Conductivity, Total Dissolved Solids and temperature of the collected water sample. A turbidity meter (TRITON TR86) instrument was used for measuring turbidity level in water. The instrument was calibrated prior to the triplicate measurements as per manufacturer guidelines.

\section{The determination of nutrients}

The concentration of phosphate and nitrates were determined using the Metrohm Ion Chromatographic Instrument as per the procedure of Modika et al.[8].

\section{The determination of heavy metals}

For preparation of heavy metal analysis, a 0.45 um yellow membrane filter was used for filtration of water samples collected from different study areas. A $10 \mathrm{ml}$ syringe was used to collect each water samples through a stainless-steel filter holder into a $10 \mathrm{ml}$ tubes, and the tubes were labelled for sample analysis. A new syringe and a new membrane filter was used for each water sample; stainless steel filter holder was washed with distilled water each time before use; a blunt was used to place and remove a membrane filter into \& from stainless steel filter holder, to avoid contamination from one water sample to another. After sample preparation, Samples were sent for duplicate analysis at the ARC Institute of Soil, Water \& Climate, in Pretoria, where a Thermo electron X series II Quadrupole Inductively Coupled Plasma Mass Spectrometer (ICP-MS) was used for heavy metals analysis.

\section{Toxic cyanobacteria gene analysis}

The extraction of the cyanobacteria genomic DNA, PCR amplification and detection of genes expressing toxicity was carried out as per procedure of Magonono et al. [5].

\section{E. Data analysis}

Microsoft excel 2020 was used to display the data in the form of graphs. The data for heavy metals was $\log 10$ transformed to cater for large disparity in the levels of metal concentrations.

\section{RESULTS AND DISCUSSION}

\section{A. Physical-chemical quality of the water}

The physical characteristics of the drinking water and raw water sources are shown in Figure 2. The $\mathrm{pH}$ readings for both water sources were within the range of 6 to 7 (Figure 2A). During July and October, the $\mathrm{pH}$ for Musina tap water was normal and within the SANS 241[9] standards ( $\geq 5$ and $\leq 9.7$ ). During July and October, the $\mathrm{pH}$ for Limpopo borehole and Limpopo weir was normal and within the DWAF (1996) standards $(6.0$ - 9.0). During July and October, the $\mathrm{pH}$ for Beitbridge town was normal and within the SAZ (2015) [10] standard (6.5 to 8.5$)$.

The electrical conductivity (EC) measurements of the Limpopo borehole water, Musina tap water, and Beitbridge tap water in October were lower than July measurements (Figure 2B). The decrease has been attributed to the drought conditions. During October, there was decrease in EC for Musina tap, which according to the SANS 241[9] standards the water is visually,

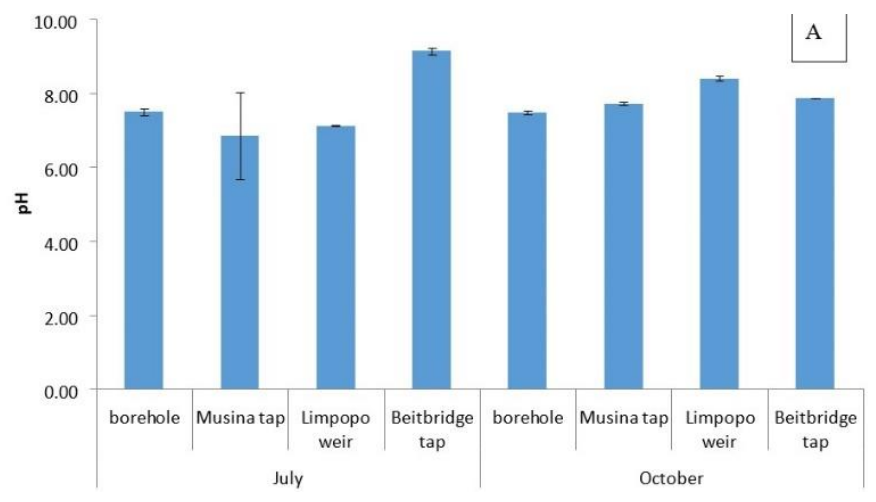




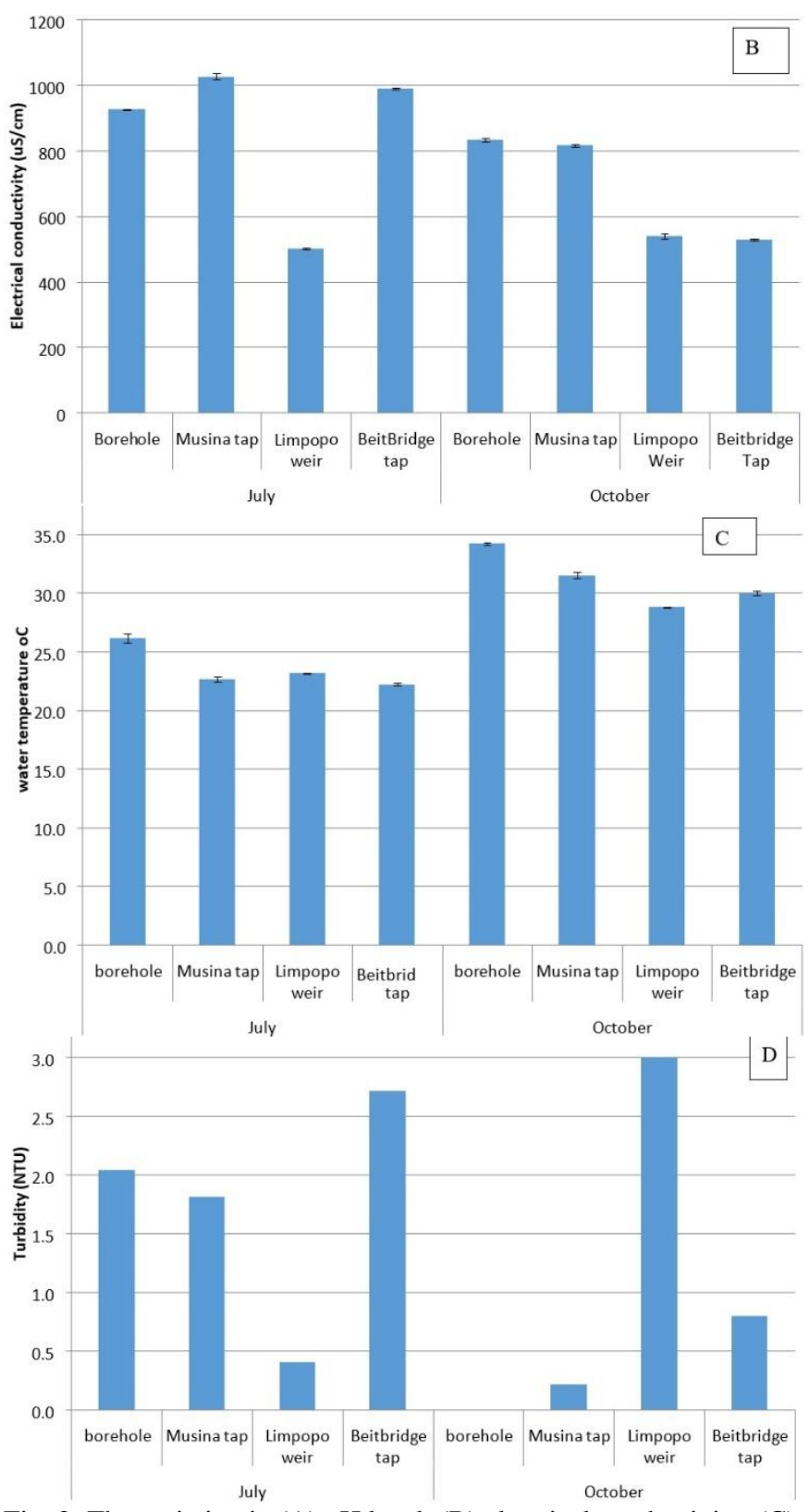

Fig. 2: The variation in (A) pH level; (B) electrical conductivity; (C) water temperature and (D) turbidity during July and October 2016.

aromatically or palatably unacceptable. During October, according to the DWAF [11] standards (170), there was decrease in EC for Limpopo borehole. During October, according to DWAF [11], there was an increase in EC in Limpopo weir. During October, according to SAZ [10] standards (40), there was an increase in EC for Beitbridge town. Increase in EC has been attributed to low number of dissolved solids in water and low temperature and decrease in EC has been attributed to high number of dissolved solids, since EC is inversely proportional to temperature and dissolved solids.

There was an increase in water temperature in both Musina tap water, Limpopo borehole, Limpopo weir, and Beitbridge town tap water in October (Figure 2C). This has been attributed to the drought conditions and exposure to high radiation and heat waves during this period. These increase in temperature together with presence of nutrients in water may encourage the growth of cyanobacteria.

There was decrease in turbidity levels for Limpopo borehole water and Musina \& Beitbridge tap water in October (Figure 2D). The turbidity levels were within the SANS 241[9] standards $(\leq 1$ and $\leq 5$ NTU), DWAF [11] standards $(0-1$ NTU), and SAZ [10] guidelines (5) for drinking water respectfully. There was increase turbidity in Limpopo weir borehole water during October, which according to DWAF [11] standards $(1-5 \mathrm{NTU})$, the water has slight chance of adverse aesthetic effects and infectious disease transmission. The increase in turbidity has been attributed to rainfall that may have occurred upstream of the study site. The Limpopo River has number of tributaries in South Africa, Zimbabwe and Botswana.

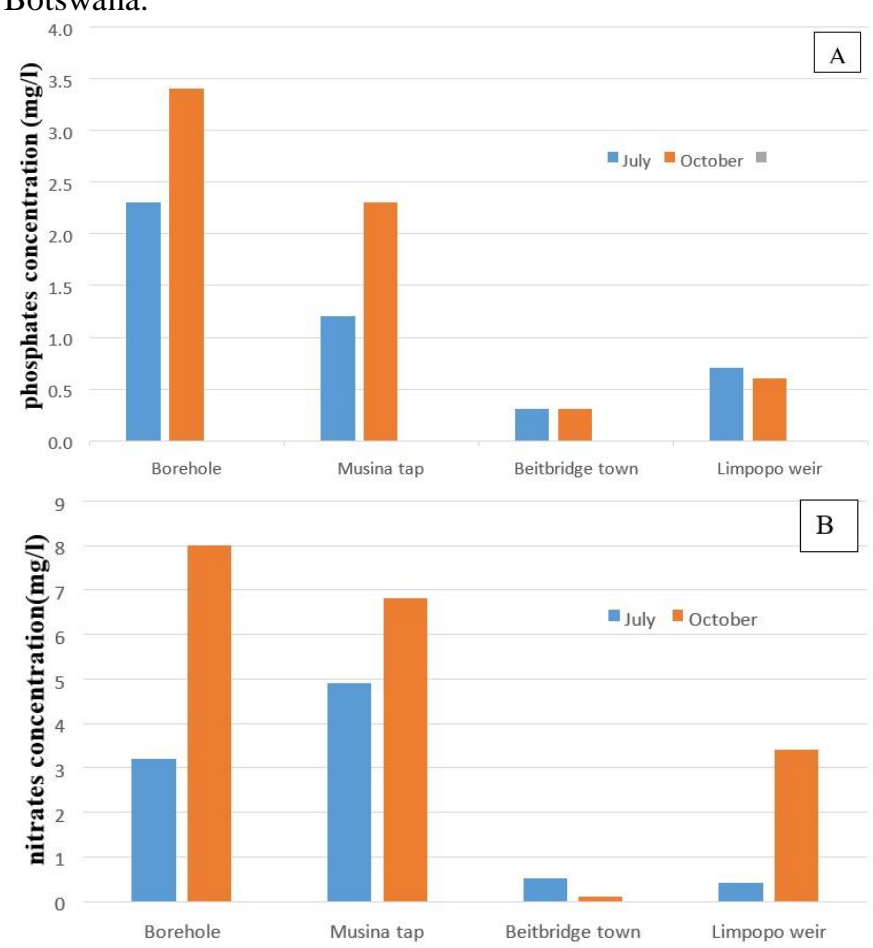

Fig. 3: The variation in (A soluble phosphates and (B) nitrates during July and October 2016 .

The study showed the presence of nitrates and phosphates in water sources (Figure 3). There was an increase of phosphates concentration in Limpopo borehole water and Musina tap water during October (Figure 3A). This was probably due to drought conditions, high temperatures and no river flows in the Limpopo River. During October, the Limpopo River ceases to flow on the surface, but subsurface flows continue to flow. Then phosphate shows a decrease in Limpopo weir during October. According to SANS 241[9] for Musina tap water, DWAF [11] for Limpopo weir and borehole water, and SAZ [10] for Beitbridge town tap water, their phosphates concentration was within the water quality standards limits.

There was an increase in nitrate concentration in Limpopo borehole, Musina tap, and Limpopo weir during October (Figure 3B). This was due to the drought condition. Nitrate shows a decrease in Beitbridge town tap water in October, which was due to water treatment. During July and October, 
according to SANS 241 [9], Musina tap water is within the water quality standard $(\leq 11 \mathrm{ppm})$. During July and October, according to the SAZ [10], Beitbridge town water is within the standards. During July and October, according to DWAF [11], Limpopo borehole and weir water are within the standards limits, with no effects. The variation in levels of nitrates in the riverbed has been attributed to denitrification process that occurs during drought periods with high temperatures [12].

The presence of phosphates and nitrates in Limpopo weirand borehole is probably due to the upstream catchment activities. Limpopo River is a transboundary river shared by four countries: South Africa, Botswana, Zimbabwe and Mozambique (downstream). The studies of Magonono et al. [5] have indicated that the nutrients, phosphates and nitrates, are linked to commercial and subsistence irrigation and sewage discharges occurring on the upstream catchment activities. Increase in phosphates are observed in surface and bottom water, thus aiding to the growth of phytoplankton (algae blooms) and causing water quality deterioration.

\section{B. The presence of heavy metals in the water sources}

The study showed the presence of heavy metals in the water sources. For Musina borehole, the results showed an increase in heavy metals, V; Cr; $\mathrm{Mn}$; $\mathrm{Co}$; $\mathrm{Cu} ; \mathrm{Zn} ; \mathrm{Se} ; \mathrm{Cd} ; \mathrm{Sb} ; \mathrm{Pb}$ and $\mathrm{Bi}$ concentration and a decrease in the levels of $\mathrm{Ni} ; \mathrm{As} ; \mathrm{Ba} ; \mathrm{Hg}$ and $\mathrm{U}$ in the raw water in October (Figure 4A). For Musina water tap, there was an increase in the concentration of the following metals: V; Cr; Zn; As; Sb; Ba and U (Figure 4B). According to DWAF [11] these metals were below the DWAF guidelines for domestic uses.

For Beitbridge water tap, the results showed an increase in heavy metals: $\mathrm{B}$; $\mathrm{V} ; \mathrm{Cr}$; $\mathrm{Co} ; \mathrm{Cu} ; \mathrm{Sb} ; \mathrm{Hg}$ and $\mathrm{Pb}$ concentration and a decrease in the levels of Ni; As; Se and $\mathrm{U}$ in October (Figure 4C). These metals are within the SAZ (2015) guidelines for drinking water. For Limpopo weir, there was an increase in the concentration of the following metals: $\mathrm{Mn} ; \mathrm{Co} ; \mathrm{Zn} ; \mathrm{Se} ; \mathrm{Sb}$ and $U$ (Figure $4 \mathrm{C}$ ). The changes in the metal levels may be attributed to the drought conditions.

The metals such as Copper $(\mathrm{Cu})$ does not have health effects and cause severe taste and staining problems since it falls below the 2000ppb guideline. The mercury $(\mathrm{Hg})$ levels were below the $6 \mathrm{ppb}$ levels in drinking waters for the towns of Musina and Beitbridge. There is no guideline value for vanadium $(\mathrm{V})$ and zinc ( $\mathrm{Zn})$ but the concentration was below 20ppb and $6 \mathrm{ppb}$ respectfully for both drinking water for Musina and Beitbridge towns.
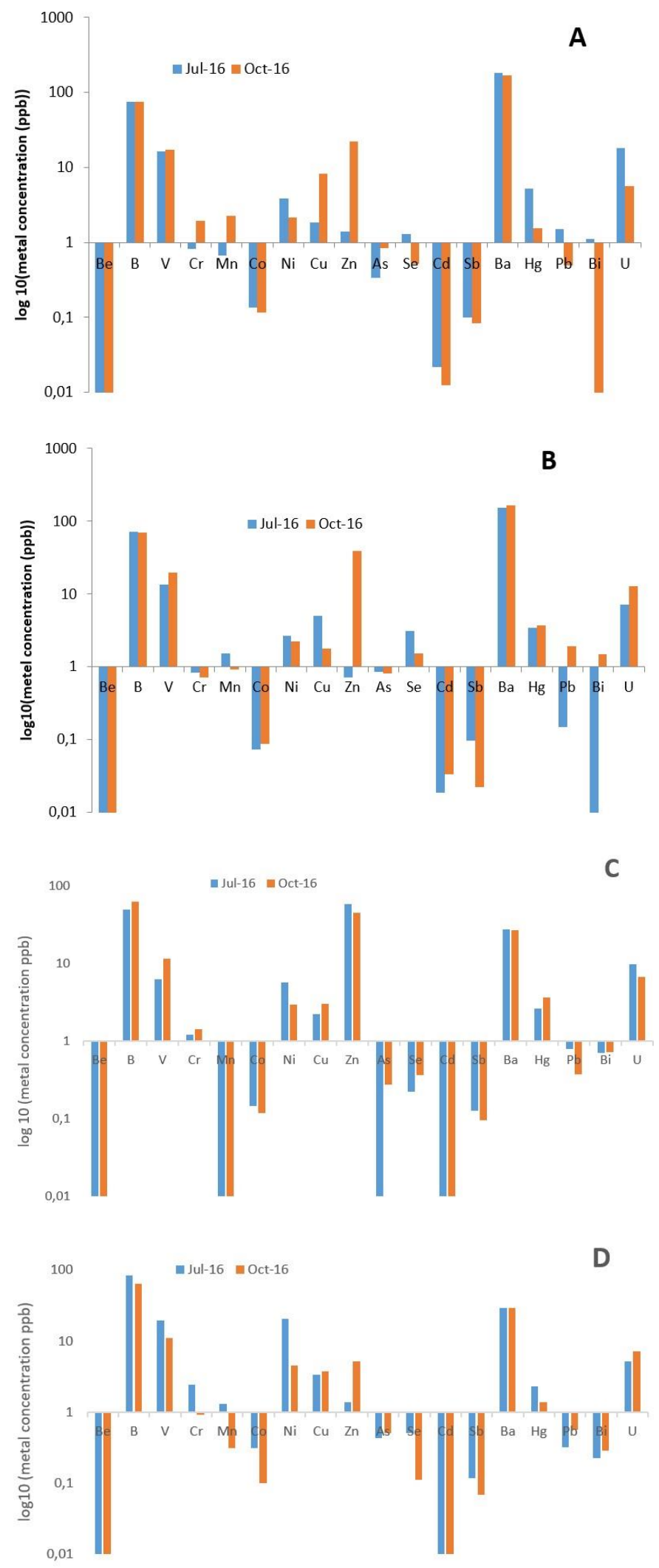

Fig. 4: The variation of heavy metals in (A) Musina borehole; (B) Musina water tap; (C) Beitbridge water tap and (D) Limpopo weir during July and October 2016.

Increase in metals are attributed to drought conditions since there are lot of sediments runoff that occur in the river, but the 
variation in decrease and increase in metals during drought was due to varying adsorption capacities of metals to suspended solids in water [13].

\section{The presence of toxic cyanobacteria in the water source}

The presence of genes expressing toxicity were found in some of the water sources. The genes expressing toxicity were positive for cylindrospermopsin (Figure 5). The cyanobacteria species, Aphanizomenon ovalisporum, Anabaena, Umezakia natans Lyngbya wollei, Raphidiopsis, Oscillatoria, Dolichospermum mendotae, Chrysosporum ovalisporum and Cylindrospermopsis, are known producers of cylindrospermopsin, a potent cyclic guanine alkaloid toxin [14-16]. The toxic cyanobacteria were found in the Limpopo River (the weir and the borehole) and then in the Musina water tap. The origin of the cyanobacteria in the Limpopo River has been attributed to upstream catchment activities (Magonono et al. 2018) and favourable environmental weather factors (heat and solar radiation, nutrients, (this study). Thus, the drought conditions prevailing during the study have worsened the situation. The switch to toxic cyanobacteria such as Anabaena circinalis and Cylindrospermopsis raciborkii has been observed in other parts of the world such as in the Darling-Barwon river basin, Australia, Portuguese reservoirs [13] and Oliphants river basin respectfully [4].

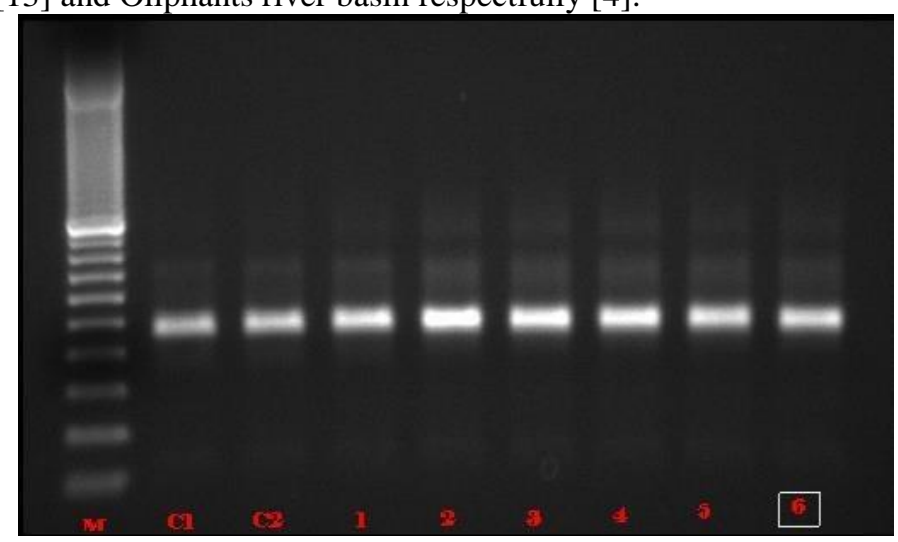

Fig. 5: An Agarose gel electrophoresis of PCR products from fragment of 487 bp using M13 and M14 primers, which are cylindrospermopsin peptide synthetase toxins. $\mathrm{M}=100 \mathrm{bp}$ ladder. $\mathrm{C} 1$ and $\mathrm{C} 2=$ positive controls. $1=$ Musina borehole water and 2=Musina tap water in July;

$3=$ Musina borehole water and 4=Musina tap water in October;

5=Limpopo weir in July; and 6= Limpopo weir in October.

The presence of cylindrospermopsin in the tap water is worrisome issue in terms of human poisonings [16]. The cylindrospermopsin are cyanotoxins which can cause human health implications such as stomach cramps, vomiting, diarrhea, fever, headache, pains in muscles and joints, body weakness, abdominal pains, nausea, sore throat, dry cough, blistering at the mouth, kidney dysfunction and liver failure , and can thus lead to death.

The genes expressing toxicity were negative for cylindrospermopsin and microcystin (Figure 6). Hence this shows no presence of toxic cyanobacteria in the Beitbridge tap water. The reason for the absence of toxic genes in Beitbridge tap water but present in Musina tap water may be attributed to water treatment processes. In Beitbridge town, the water treatment process follows the normal conventional water treatment train, coagulation and flocculation using coagulant such as iron sulphate and aluminum chloride [15].

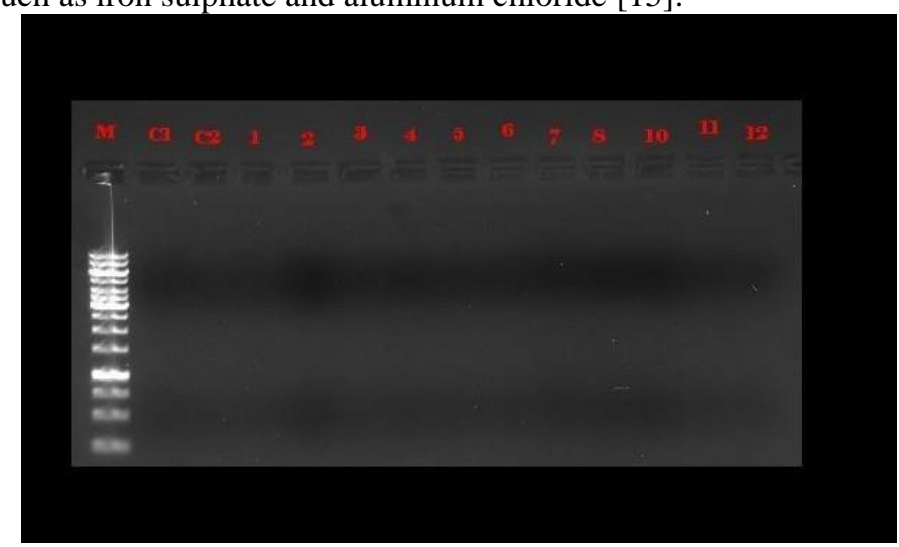

Fig. 6: An Agarose gel electrophoresis of PCR products from fragments of $487 \mathrm{bp}$ using all six set of primers. $\mathrm{M}=100 \mathrm{bp}$ ladder. $\mathrm{C} 1$ and $C 2=$ positive controls. Lane 1-12, shows water samples of Beitbridge during July and October using all set of primers. $1=$ Beitbridge town in July and $2=$ Beitbridge town in October using $27 \mathrm{~F}$ and $809 \mathrm{R}$ primers. $3=$ Beitbridge town in July and 4=Beitbridge town in October using 740F and 1494R primers. 5=Beitbridge town in

July and $6=$ Beitbridge town in October using mcyA-Cd F and mcyA-Cd R primers. 7=Beitbridge town in July and 8=Beitbridge town in October using HEPF and HEPR primers. 9=Beitbridge town in July and 10=Beitbridge town in October using PKS M4 and PKS M5 primers. $11=$ Beitbridge town in July and $12=$ Beitbridge town in October using M13 and M14.

These coagulants can remove the entire cyanobacteria cell without losing the cyanobacterial cell wall and this may imply the absence of toxic cyanobacteria cells in the drinking water. In the rapid sand filtration, the cyanobacteria cells are also trapped by sand bed and then removed as entire cyanobacterial cells [17]. In the case of Musina town, the borehole water is simply chlorinated, and this implies that the toxic cyanobacteria cells are lysed, and DNA material is present in the drinking water [18]. Hence the positive detection of genes expressing toxicity in the drinking water using the molecular techniques.

\section{CONCLUSION}

The study showed the presence of genes expressing toxicity for the cylindrospermopsin cyanotoxin in some of the water samples. The cyanotoxin has been attributed to toxic cyanobacteria which proliferate due to favourable environmental weather conditions. The $\mathrm{pH}$ was alkaline for all the water samples. The water temperature, high electrical conductivity was above $25{ }^{\circ} \mathrm{C}$ and $500 \mu \mathrm{S} / \mathrm{cm}$ respectfully during October. The nutrients, phosphates and nitrates were high in the raw water supplies (Limpopo borehole and weir) during the October period. The concentrations of heavy metals were higher in October than in July. The drought conditions, heat waves, and solar radiation probably contributed to the increased levels of metals and nutrients in the water sources.

Further research is required to determine the level of cyanotoxins in the drinking water and to identify cyanobacteria species in raw water supply and drinking water. It is further recommended that the Musina town should adopt water 
treatment methods that removes or flocculates the entire cyanobacteria cells without losing the cells.

\section{ACKNOWLEDGMENT}

The study was funded by Eskom through their Tertiary Support Program (TESP), project E320. We are grateful to Prof Shonhai, Department of Biochemistry, University of Venda for DNA work.

\section{REFERENCES}

[1] Delpla I, Jung AV, Baures E, Clement M, Thomas O. Impacts of climate change on surface water quality in relation to drinking water production. Environment international. 2009 Nov 1;35(8):1225-33.

https://doi.org/10.1016/j.envint.2009.07.001

[2] Trenberth KE, Dai A, Van Der Schrier G, Jones PD, Barichivich J, Briffa KR, Sheffield J. Global warming and changes in drought. Nature Climate Change. 2014 Jan;4(1):17-22. https://doi.org/10.1038/nclimate2067

[3] Manderson A, Kubayi N, Drimie S. The impact of the South African drought as experienced by small-holder farmers over the June 2015-February 2016 period in the Mopani District of Limpopo, South Africa. Stellenbosch: Agro-ecology Awareness Project, South African Food Lab. 2016 Jun.

[4] Dabrowski J, Oberholster PJ, Dabrowski JM. Water quality of Flag Boshielo Dam, Olifants River, South Africa: historical trends and the impact of drought. Water SA. 2014 Apr 9;40(2):345-58. https://doi.org/10.4314/wsa.v40i2.17

[5] Magonono M, Oberholster PJ, Shonhai A, Makumire S, Gumbo JR. The presence of toxic and non-toxic cyanobacteria in the sediments of the Limpopo River Basin: Implications for human health. Toxins. 2018 Jul;10(7):269. https://doi.org/10.3390/toxins10070269

[6] Dzebu W. Statement In Relation To Water Supply Challenges in Musina, 2017.

http://www.musina.gov.za/index.php/34-latest-news/456-statement-in-re lation-to-water-supplyhttp://www.musina.gov.za/index.php/34-latest-ne ws/456-statement-in-relation-to-water-supply-challenges-in-musinachall enges-in-musina (date accessed 26/03/2014).

[7] International Bank for Reconstruction and Development/The World Bank. Beitbridge Emergency Water Supply and Sanitation Project Effects on service access and citizen confidence in government institutions. September 2014 https://www.wsp.org/sites/wsp/files/publications/WSP-Beitbridge-Zimb abwe-WSS-Impact-Assessment-Report.pdf (date accessed 16/10/2020).

[8] Modika LL, Matsheketsheke L, Gumbo JR. assessment of silver metal released into wastewater after using a silver deodorant. WIT Transactions on Ecology and the Environment. 2018 Aug 21;228:121-9. https://doi.org/10.2495/WP180131

[9] South Africa National Standards (SANS 241). South Africa drinking water standards, 2015.

[10] Standards Association of Zimbabwe (SAZ). Zimbabwe drinking water standards. 2015.

[11] Department of Water Affairs and Forestry (DWAF), South African Water Quality. Guidelines (second edition). Volume 1: Domestic Use. 1996.

[12] Zwolsman JJ, Van Bokhoven AJ. Impact of summer droughts on water quality of the Rhine River-a preview of climate change?. Water Science and Technology. 2007 Aug;56(4):45-55. https://doi.org/10.2166/wst.2007.535

[13] Mosley LM. Drought impacts on the water quality of freshwater systems; review and integration. Earth-Science Reviews. 2015 Jan 1;140:203-14. https://doi.org/10.1016/j.earscirev.2014.11.010

[14] Pearson LA, Dittmann E, Mazmouz R, Ongley SE, D’Agostino PM, Neilan BA. The genetics, biosynthesis and regulation of toxic specialized metabolites of cyanobacteria. Harmful Algae. 2016 Apr 1;54:98-111. https://doi.org/10.1016/j.hal.2015.11.002

[15] Falconer IR, Humpage AR. Health risk assessment of cyanobacterial (blue-green algal) toxins in drinking water. International journal of environmental research and public health. 2005 May;2(1):43-50. https://doi.org/10.3390/ijerph2005010043

[16] Westrick JA, Szlag DC, Southwell BJ, Sinclair J. A review of cyanobacteria and cyanotoxins removal/inactivation in drinking water treatment. Analytical and bioanalytical chemistry. 2010 Jul 1;397(5):1705-14 https://doi.org/10.1007/s00216-010-3709-5

[17] Hoeger, S. J., Shaw, G., Hitzfeld, B. C., \& Dietrich, D. R. (2004). Occurrence and elimination of cyanobacterial toxins in two Australian drinking water treatment plants. Toxicon, 43(6), 639649.

https://doi.org/10.1016/j.toxicon.2004.02.019

[18] Szlag, D. C., Sinclair, J. L., Southwell, B., \& Westrick, J. A. (2015). Cyanobacteria and cyanotoxins occurrence and removal from five high-risk conventional treatment drinking water plants. Toxins, 7(6), 2198-2220. https://doi.org/10.3390/toxins7062198

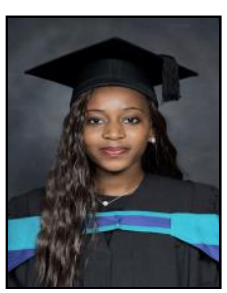

Ms Tshifhiwa Shelter Muntswu was born in Tshimbupfe Thondoni village, Makhado local Municipality, in Limpopo province of South Africa. The author graduated with a bachelor of Environmental Science Honours in ecology and resources management from the University of Venda in 2017. She was appointed as an INTERN in 2018, and in 2020 as an ASSISTANT DIRECTOR at the National Disaster Management Center (NDMC), Department of Cooperative Governance (DCOG). She completed her mini dissertation on the impact of drought on drinking water quality for Musina and Beitbridge towns in 2017, and currently have research interest on the assessment of Covid-19 impacts in rural and informal townships.

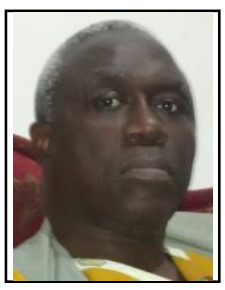

Professor Jabulani Ray Gumbo graduated with a $\mathrm{PhD}$ in Water Resources Management from University of Pretoria in 2007. He was awarded the second-best student poster price at the 12th International Conference on Harmful Algae in 2006 and the study was then published in the prestigious conference proceedings after a rigorous peer review process. This author became a Member (M) of International Society for the Study of Harmful Algae; International Mine Water Association; Water Institute of Southern Africa; Microscopy Society of Southern Africa and South African Council for Natural Scientific Professions. In 2008, he was appointed as a senior lecturer at University of Venda and in 2016 he was appointed as Associate Professor. He is the first or second author of more than 86 research outputs ( 3 patents, 38 peer reviewed papers with more than thirds of these published in international journals with an impact factor; 41 peer reviewed conference proceedings and 3 technical reports and four book chapters). He acts as a reviewer for NRF in the fields of cyanobacteria and has been invited to be a reviewer for Ohio Sea Grant Proposal (USA); Journal of Applied Phycology (Australia); Bioresource Technology

Journal (BITE) (USA); Journal of Freshwater Ecology (Britain); South African Journal of Science (SAJS) (South Africa) and African Journal of Biotechnology (AJB) (Nigeria). He lectures students at undergraduate and postgraduate levels in the fields of water treatment; water quality management; water law and institutions; rural water supply and sanitation; data information systems and water quality principles and he supervises several Honours, Masters and $\mathrm{PhD}$ students in the fields of water quality management; aquatic ecotoxicology and limnology and water treatment. 